Article

\title{
Analyzing Forces to the Financial Contribution of Local Governments to Sustainable Development
}

\author{
Manuel Pedro Rodríguez Bolívar*, Andrés Navarro Galera, Laura Alcaide Muñoz \\ and María Deseada López Subires \\ Department of Accounting and Finance, University of Granada, Campus Universitario de Cartuja, s/n, \\ 18071 Granada, Spain; angalera@ugr.es (A.N.G.); lauraam@ugr.es (L.A.M.); desirels@ugr.es (M.D.L.S.) \\ * Correspondence: manuelp@ugr.es
}

Academic Editor: Giuseppe Ioppolo

Received: 5 June 2016; Accepted: 6 September 2016; Published: 10 September 2016

\begin{abstract}
In many countries, the economic crisis brought high volumes of deficit and debt in public entities, which jeopardized the ability of governments to continue providing public services and caused considerable imbalances of economic growth in different regions. In this context, from the recognition of the linkage between economic development and efficiency in public management, previous research indicates that local governments are called to play a key role in promoting sustainable development through environment, economic and social policies based on financial sustainability of the public services. This paper aims to identify influencing factors on the financial sustainability of local governments, as an indicator of their capacity to maintain the delivery of public services over time. Based on a sample of 139 Spanish municipalities with large population for the period 2006-2014, our findings reveal the influence of variables such as the unemployment rate by sector, the dependent population, the immigrant population and the level of education of the population, on the financial sustainability in local governments, providing new useful knowledge to managers, policymakers, researchers and others stakeholders interested in the sustainability of public services.
\end{abstract}

Keywords: economic growth; financial sustainability; sustainable development

\section{Introduction}

At the international level, the economic crisis has undermined the capacity of Local Governments to continue provided public services to society. Under this delicate financial situation, the unequal economic development created significant imbalances between regions and municipalities especially vulnerable to problems like the budget deficit and public debt [1,2].

In Spain, the disproportional increase in spending relative to revenues evolution has caused high levels of deficit and debt in the public sector, challenging the size and financial viability of public services. In fact, the Fiscal Sustainability Report [3] states that countries such as Spain, Portugal, Italy or Greece have sustainability gap above the average of the European Union, in the short, medium and long term. Indeed, since 2008 in this countries a strong imbalance in development and economic growth has led to a greater imbalance between regions [4] (see Table 1), jeopardizing the ability of governments to continue to provide services in the future [5-7]. 
Table 1. Differences between Regions.

\begin{tabular}{|c|c|c|c|c|c|c|c|}
\hline Regions & Debt/pc ${ }^{1, *}$ & $\mathrm{GDP} / \mathrm{pc}{ }^{2}$ & Budget Result/pc ${ }^{3}$ & Expenditures/pc ${ }^{3}$ & $\begin{array}{c}\text { Immigrant } \\
\text { Population }^{2}\end{array}$ & $\begin{array}{c}\text { Dependent } \\
\text { Population Rate }{ }^{2}\end{array}$ & $\begin{array}{c}\text { Unemployment } \\
\text { Rate }^{4}\end{array}$ \\
\hline Andalucía & 20.90 & 16,577 & -223.39 & 3016.67 & 7.87 & 49.93 & 34.23 \\
\hline Aragón & 18.30 & 24,713 & -445.91 & 3577.07 & 11.26 & 55.33 & 18.65 \\
\hline Principado de Asturias & 16.70 & 19,727 & -252.41 & 3643.96 & 4.25 & 54.27 & 20.78 \\
\hline Islas Baleares & 29.50 & 23,498 & -416.88 & 3928.62 & 18.41 & 45.71 & 18.88 \\
\hline Canarias & 14.80 & 19,238 & -180.54 & 3226.41 & 12.69 & 42.76 & 31.08 \\
\hline Cantabria & 20.50 & 20,237 & -336.36 & 3985.35 & 5.91 & 51.92 & 18.42 \\
\hline Castilla y León & 17.90 & 21,063 & -238.50 & 3404.70 & 5.88 & 57.78 & 20.28 \\
\hline Castilla-La Mancha & 35.30 & 17,636 & -321.85 & 3147.78 & 9.43 & 52.74 & 28.50 \\
\hline Cataluña & 32.70 & 26,624 & -718.99 & 3987.68 & 14.49 & 52.58 & 19.88 \\
\hline Comunitat Valenciana & 38.40 & 19,693 & -485.13 & 3334.17 & 14.78 & 51.81 & 23.48 \\
\hline Extremadura & 18.30 & 15,457 & -386.49 & 3927.68 & 3.43 & 53.28 & 29.96 \\
\hline Galicia & 18.50 & 19,661 & -195.00 & 3416.53 & 3.57 & 56.80 & 20.87 \\
\hline Comunidad de Madrid & 12.60 & 30,755 & -416.92 & 3453.44 & 13.63 & 49.01 & 18.00 \\
\hline Región de Murcia & 25.50 & 18,325 & -524.95 & 3354.88 & 14.72 & 50.45 & 27.26 \\
\hline C. Foral de Navarra & 18.10 & 27,709 & -234.09 & 5688.29 & 9.29 & 54.48 & 14.92 \\
\hline País Vasco & 14.10 & 29,277 & -292.83 & 4478.33 & 6.46 & 54.98 & 16.60 \\
\hline La Rioja & 16.80 & 24,601 & -304.07 & 3749.19 & 12.54 & 54.46 & 17.17 \\
\hline
\end{tabular}

Source: ${ }^{1}$ Bank of Spain; ${ }^{2}$ INE (Statistic Institute of Spain—www.ine.es); ${ }^{3}$ Ministry of Finance and Public Administration (www.minhap.gob.es); ${ }^{4}$ Public Employment Service of Spain (www.sepe.es); Note: * Debt/GDP $\times 100$ Following the Protocol of Excessive Deficit. Year 2014. 
This worrying financial situation has attracted policymakers' attention, specifically regarding local governments, whose high debt levels and budget deficits, together with its harmful effects on the economic development, have caused a process of policy reforms aimed at promoting efficiency, balanced budgets and, mainly, the financial sustainability of public services $[6,8,9]$.

Indeed, the international situation of the financial crisis has led financial sustainability to become a key concept in governmental entities even more important than the other dimensions for Public Sector management, which has attracted the attention of researchers [10,11]. In parallel, international organizations such as EU (European Union) [3,12], EC (European Commission) [13], IMF (International Monetary Fund) [14] and NAO (National Audit Office) [15] have recommended governments to adopt strategies for the financial sustainability of public policies.

For this purpose, international bodies $[3,12,15-17]$ and previous research have recognized the usefulness of government financial statements for reporting on the sustainability of public policies. More concretely, following the pronouncements of the IFAC $[16,18]$ and findings of previous studies [2,19], the income statement, which includes the revenues and expenditures in accrual basis, enables users to assess, on the one hand, the capacity of the governments to continue providing at least the same volume of goods and services and, on the other hand, the level of resources that will be needed in the future to continue to fulfill its public services delivery obligation.

Therefore, in line with the findings of previous research [19-22], an analysis of risk or drivers factors for financial sustainability can help public managers and policymakers to monitor and maintain financial sustainability.

Previous research has studied the influence of political and socioeconomic factors on the financial transparency of local governments [6,23], while other studies have addressed the motivations of governments to publish sustainability reports. In parallel, other studies have analyzed factors influencing the tax burden $[24,25]$, and public debt $[6,26]$. Although to date, previous literature [27] highlighted the continuing effects of the economic crisis on the financial local governments health and some studies have tried to measure it [28-31], the analysis of the explanatory variables of financial sustainability of local governments requires more attention [2,32], especially about variables such as human capital, companies' developments, unemployment, economic level or population structure, which motivates the opportunity and interest of this study.

This paper aims to identify factors that may influence the financial sustainability of the local governments. Given that the local governments manage a huge volume of budgets, provide a great variety and quality of public services, and the financial crisis influence on the quality and amount of public services delivery.

The local governments are obliged by the Law 7/1985 [33] to provide different services (such as street lighting, waste collection, public parks, social services, cultural services and environmental protection), and for this reason their revenues involve their own taxes (such as property taxes and motor vehicle taxes) as well as transfers received from national and regional governments (the participation of local government in national and regional taxes). The own taxes of local governments are regulated by national rules and each local government is only allowed to choose the tax rate, which has to be between a minimum and maximum for each tax [34].

In this paper, we analyze the impact of demographic and socioeconomic variables in the evolution of financial sustainability, taking a sample of 148 large Spanish Local Government during the period 2006-2014. Our findings have identified variables such as unemployment rate by sector, economic level, the dependent population, which may influence the financial sustainability of Local Governments, whose knowledge is very relevant to managers, policymakers, users of public services, voters and others stakeholders interested in public service sustainability.

\section{Research Questions}

In line with the conclusions of international bodies [12-14,17] and previous research [19-22,35], it is interesting and timely to consider whether the behavior of demographic and socioeconomic 
variables can affect the financial sustainability of local governments. Consequently, with the objective of this study in mind, we propose the following research questions, along with their academic support.

(1) Does the human capital formation influence on the financial sustainability of Local Governments?

Previous research has shown that one of the main important stimulants in the development and economic growth of a region is the educational level of the population [36-40]. According to prior research [37-42], a higher educational level of the population could mean higher wages and thus, higher amounts of direct and indirect taxes, increasing the resources of Local Governments, and therefore, their financial capacity of promoting economic development.

(2) Does the companies concentration affect the financial sustainability of Local Governments?

Baptista et al. [43] concluded that higher levels of entrepreneurship promote economic development and job creation. In this sense, following Sutaria and Hicks [44] implies an increase in tax revenues and private consumption, promoting financial capability the governments. However, authors such as Fritsch and Mueller [45] show that the companies' concentration in a region can have both positive and negative consequences on their development. In the early years, the creation of enterprises will have a positive effect, especially in the creation of regional employment. Instead, after the first years, this positive effect trends to decrease depending on the situation where the company is located.

\section{(3) Does the unemployment rate influence on financial sustainability of Local Governments?}

The influence of the unemployment rate on the financial sustainability should be analyzed, especially in the crisis times when this rate has substantially increased at European level, although its effect has been different between countries due to the level of economic development, labor market stability and policies adopted [46]. According to the Fiscal Sustainability Report [3], a higher rate of unemployment has a negative influence on the country's production and income received by the different levels of government (central, regional and local). In parallel, the preliminary investigation revealed that the increase in unemployment has adverse effects on social spending [47], indebtedness [6] and government revenues [48]. In addition, due to the economic crisis, in Spain, the unemployment rate has had an uneven behavior between the different economic sectors (agriculture, industry, building and services) (Public State Employment Service-SEPE). Therefore, considering the above mentioned and the three dimensions of sustainability [17], it is interesting to analyze the influence of the unemployment rate by sector on the financial sustainability of local governments.

(4) Does the economic level of a region impact on the financial sustainability of Local Governments?

Due to the state regulation, Spanish local governments are only able to set a rate (between a minimum and maximum) in five specific taxes (property tax, tax on motor vehicles, tax on the increase in value of urban land, tax on building, installations and other work and luxury tax) and to participate in the national taxes such as PIT (Personal Income Tax) or VAT (Value Added Taxes). Therefore, this limited capacity of local governments does not allow them to create new taxes or to directly benefit from an increase of GDP, since the GDP depends on the consumption of the population and does not provoke a direct increase in the municipal collection taxes.

In this regard, authors such as Capalbo and Grossi [49] found that an increase in GDP could lead to an increase in regional per capita income, increasing the capacity of the population to finance municipal services. This partnership would promote public revenues [50] and decreased debt [51], which would cause a positive effect on the finances of local governments. In the same vein, Ghosh et al. [52] and Potrafke and Reischmann [53] concluded that the economic level of a region is a key to analyze the financial viability of it, to the extent that it affects the ability of local governments to provide public services element and thus boosting the sustainability of regional development. It is, therefore, interesting to analyze the effect of changing the economic level of a territory on the financial sustainability of Local Governments. 
(5) Does the population structure affect financial sustainability of Local Governments?

Previous studies have highlighted that the population structure, especially population growth, dependent population and immigrant population, could affect the economic wealth of Local Governments. In this sense, population growth increases new demands of resources and services [54-56] that involve an increase in expenditures but do not always involve an increase in public revenues, since the increase of the tax collection does not depend only on the population growth, but also on the financial capacity of the population and of the economic activity. Indeed, the uneven population growth between regions affects differently in the regional needs of providing services such as water services, garbage collection, energy, food, healthcare or education [55], influencing the regional economic development. Therefore, an increase in the population could bring an increase in the public borrowing and spending [57], increasing the public debt of local authorities [6]. Therefore, the population growth is expected to be a negative factor for the ability of local government to contribute to sustainable development because it could lead to new needs in the provision of public services increasing local governments' debt and expenditures [7,58].

On the other hand, Kloha et al. [24] believe that the size of the population aged over 65 years and under 16 years is inversely related to government revenue and expenditure and has a significant influence on increased fiscal distress, and hence, could affect the sustainable economic development. The elderly population is growing faster than the rest, and thus could influence on the population balances, which is the main demographic component [59], and on financial sustainability $[16,60]$. The needs of the dependent population (under 16 and over 65) lead to increase the public services provided. Therefore, this population has a negative influence on the per capita spending and taxation, and therefore on the budget balance $[57,61]$ and the financial capacity of local authorities $[25,62]$. In addition, international reports, such as the Fiscal Sustainability Report [3], Sustainability Report 2009 [63] and Reporting on the Long-Term Sustainability of a Public Sector Entity's Finances [16], recognize that the existence of an ageing population may influence financial sustainability. Therefore, these variables are expected to be inversely related to the financial sustainability of local government and hence, they could jeopardize to provide public services and economic development.

Likewise, immigration could affect the financial sustainability since this population could soften the negative effect of the great increase of elderly population, helping to maintain the population balance and the sustainability of pension system [60,64]. However, an increase in the immigrant population leads to new demands for public services and this could turn into a tendency to raise the level of accumulated debt $[6,65]$ and public expenditures $[57,66]$. Moreover, prior research has identified that immigrants have a negative influence on the financial performance of public administrations [48], and it positively associated with the tax burden [47]. Therefore, immigration cause an additional load on social welfare, education and health systems, which could be non-covered by their taxes, increasing the pressure on public services and influencing negatively on the financial performance. In this line, it could exist a negative influence of the immigrant people on the financial sustainability of local entities.

\section{Methodology}

\subsection{Sample Selection}

The worrying financial situation has attracted the policymakers' attention, specifically regarding local governments together with its harmful effects on the economic development, have caused a process of policy reforms aimed at promoting efficiency, balanced budgets and, mainly, the financial sustainability of public services [9]. In fact, the financial effort carried out by the Spanish local governments has allowed them to achieve the budgetary stability objective, since the whole of the local governments has a surplus of 5.938 millions of euros in 2014 [67].

Our sample is composed of 148 Spanish municipalities, those catalogued as large population municipalities by the Law 57/2003, of measures for the modernization of local government, during the 
period 2006-2014. As noted previously, these local governments have to provide the most variety of public services participation in national and regional taxes.

However, the availability of the information has allowed us to analyze only data for 139 municipalities (93.91\%). The reasons of this sample respond to the following detail. First, because local governments are the public level closest to citizen due to the legislative and political reforms in Spain and the successive process of decentralization of public services $[19,47,68]$. Second, during crisis years, the local governments became the main concern of the central and regional governments due to their high deficit and debt. In this regard, the Spanish local governments have a limited capacity to collect taxes, since due to the state regulation they can only set a rate of taxes. Therefore, a significant proportion of their budget is based on the participation in the national taxes such as PIT or VAT. Therefore, the high deficit and debt together with this limited capacity of tax collection could provoke a considerable loss of their financial sustainability.

Third, according to numerous previous studies on finances of local governments $[2,6,19,25,47,48]$ municipalities with a large population have been chosen for two reasons. These municipalities cover more than $50 \%$ of the Spanish population, so the effects of local government policies on sustainable growth include a large number and variety of stakeholders $[3,69]$. In addition, the accounting system of these municipalities is more developed and similar to those advocated by the International Financial Reporting Standards for agencies public [70]. Therefore, they are more appropriate to measure the financial sustainability of public services than the accounting system used by the municipalities of smaller dimension.

\subsection{Variables}

\subsubsection{Dependent Variable}

Previous research has highlighted that the financial sustainability is a complex and multidimensional concept by definition [27-31]. In this sense, Wang et al. [31] tried to measure financial condition, using four dimensions in cash, budget, long-run and service-level solvencies and eleven financial condition indicators. Similarly, Hendrick [30] and Rivenbark et al. [28] presented a framework for assessing the financial health and financial condition of local governments, developed different indices for some dimensions of the framework. In addition, recent studies [27] have continued to analyze how to measure the financial sustainability. Therefore, to date, we can find a plethora of measures available in the academic doctrine, all of them with support on accounting information, which keeps the debate alive.

In our empirical analysis, the dependent variable is the financial sustainability of the local government. Following the pronouncements of EC [13] and EU [12] and according to the Law 2/2012, about the budgetary stability and financial sustainability, financial sustainability can be defined as the ability to finance public services without compromising the future capacity or incurring risks of spending cuts or tax increases. More specifically, IFAC [17] and CICA [71] define the financial sustainability as the ability to meet service delivery and financial commitments, applying current policies and maintaining them in the future without causing the debt to rise continuously. In this line, according to IFAC $[16,17]$, the financial sustainability of governments is a broad concept linked to the concept of inter-period equity or intergenerational equity, which covers three dimensions: debt, revenues, and services.

In this regard, several international organizations $[3,12,15,17]$ have pointed out that the financial statements of governments are called to play an essential role in the measurement and management of financial sustainability of services public, especially the performance statement, also named as income statement (IPSAS No. 1 [18]). This financial statement includes all the revenues and expenditures under accrual basis. Under the accounting model provided by IPSAS [18] the balance of income statement is obtained by the difference between total revenues and total expenditures, including taxes, funding received, wages, current expenditures, financial expenditures and government subsidies, 
among others. In fact, IFAC [16] and some previous studies [2,19] indicate that the analysis of the income statement based on the accrual basis allows to assesses, on the one hand, the capacity of governments to continue providing at least the same current level of public services and, on the other hand, the level of resources that will be needed in the future to meet the obligations. Therefore, the accounting information provided by the income statement adequately meets the scope of the definition of financial sustainability proposed by EC, EU, IFAC and CICA.

Following IFAC [17], EU [3], EC [13] and previous studies [11,72], the information contented in the income statement reflects a direct approach to two dimensions of financial sustainability (revenues and services) and, indirectly, to the debt dimension, due to its strong link with the volume of expenditure. In fact, the income statement involves the effect of the debt, since it includes the financial expenditures which are a magnitude strongly associated with the volume of debt because a higher volume of debt, higher loan interest. According to the accounting model of IPSAS (IFAC), the income statement includes the accrued financial expenditures on short-term debt and long-term debt.

However, the current income statement is not sufficient to assess the financial sustainability of governments, since it includes revenues and expenditures from extraordinary activities that will not be repeated in the future. Therefore, an adequate measurement of the financial sustainability of local governments could be the adjusted income statements which do not include the revenues and expenditures whose probability of future occurrence is very low, in order to enhance its usefulness as a measure of ability to maintain public services over time to encourage a sustainable economic development.

Therefore, as the Table 2 shows, the dependent variable of our study is calculated using the income statement adjusted, i.e., elimination the effect of the extraordinary revenues and expenditures, following the recommendations of international organizations $[3,12,17]$ and previous research $[8,32,35,73]$. Therefore, we understand the adjusted income as the most comprehensive standpoint to measure the financial sustainability of the public services, in the same line that previously mentioned international organizations and academic studies.

Table 2. Dependent variable. Financial sustainability: Adjusted Income Statement.

\begin{tabular}{lc}
\hline \multicolumn{1}{c}{ Concept } & Amount \\
\hline Income statement for the financial year obtained by applying the current IPSAS & $(1)$ \\
Negative entries for extraordinary activities & $(2)$ \\
Positive entries for extraordinary activities & $(3)$ \\
\hline $\begin{array}{l}\text { Corrected income statement for the financial year (intergenerational equity for } \\
\text { financial sustainability) }\end{array}$ & $(1)+(2)-(3)$ \\
\hline
\end{tabular}

Source: own elaboration.

\subsubsection{Independent Variables}

Different international organizations $[3,16,63]$ and prior research $[6,19,47,57]$ maintain that there are two types of factors which can affect public debt and financial health of government entities, in particular, demographic and socioeconomic factors.

In this line, taking into account the three dimensions of financial sustainability proposed by the IFAC (debt, income, and demand) [17] and the research questions explained in Section 2, we selected 3 demographic variables (population growth, dependent population, immigrant population) and 4 socioeconomic variables (human capital, unemployment rate, corporate concentration and economic level) which are expected to be explanatory variables of the financial sustainability of local governments. In this sense, Table 3 shows the dependent and independent variables used, their definition, source, and measurement, based on the explanation provided in Section 2. 
Table 3. Dependent and Independent Variables.

\begin{tabular}{|c|c|c|c|c|}
\hline Variables & Acron. & Description & Source & Measurement \\
\hline Financial Sustainability & FS & Adjusted Income Statement & $\begin{array}{l}\text { Local government financial } \\
\text { statement }\end{array}$ & $\begin{array}{l}\text { Corrected income statement }{ }^{*} \text { for the financial year } \\
\text { per capita }\end{array}$ \\
\hline Population Growth & GPOP & $\begin{array}{l}\text { Population residing in the } \\
\text { municipality }\end{array}$ & INE (www.ine.es) & $($ Population $\mathrm{t} /$ Population $(\mathrm{t}-1)) \times 100 ; \mathrm{t}=$ year \\
\hline Dependent Population under 16 & DP16 & $\begin{array}{l}\text { Population aged under } 16 \text { years } \\
\text { residing in the municipality }\end{array}$ & INE (www.ine.es) & Population aged under 16 years/labor force \\
\hline Dependent Population over 65 & DP65 & $\begin{array}{l}\text { Population aged over } 65 \text { years } \\
\text { residing in the municipality }\end{array}$ & INE (www.ine.es) & Population aged over 65 years/labor force \\
\hline Immigrant Population & INM & $\begin{array}{l}\text { Immigrant population residing } \\
\text { in the municipality }\end{array}$ & INE (www.ine.es) & $\%$ Immigrant population \\
\hline $\begin{array}{l}\text { Labor force with higher } \\
\text { education }\end{array}$ & EDU_s & $\begin{array}{l}\text { Percentage of labor force with } \\
\text { higher education }\end{array}$ & IVIE (www.ivie.es) & labor force with higher education/labor force \\
\hline $\begin{array}{l}\text { Labor force with intermediate } \\
\text { education }\end{array}$ & EDU_m & $\begin{array}{l}\text { Percentage of labor force with } \\
\text { intermediate education }\end{array}$ & IVIE (www.ivie.es) & $\begin{array}{l}\text { labor force with intermediate education/ } \\
\text { labor force }\end{array}$ \\
\hline Companies concentration & $\mathrm{CC}$ & Companies concentration & Caja Duero; INE (www.ine.es) & Companies/1000 inhabitants \\
\hline $\begin{array}{l}\text { Unemployment rate in } \\
\text { Agricultural sector }\end{array}$ & AGRI & $\begin{array}{l}\text { Unemployment rate in } \\
\text { Agricultural sector }\end{array}$ & SEPE (www.sepe.es) & $\begin{array}{l}\text { Unemployed people in the agricultural sector/ } \\
\text { labor force }\end{array}$ \\
\hline $\begin{array}{l}\text { Unemployment rate in the } \\
\text { Industrial sector }\end{array}$ & IND & $\begin{array}{l}\text { Unemployment rate in the } \\
\text { Industrial sector }\end{array}$ & SEPE (www.sepe.es) & $\begin{array}{l}\text { Unemployed people in the industrial sector/ } \\
\text { labor force }\end{array}$ \\
\hline $\begin{array}{l}\text { Unemployment rate in the } \\
\text { building sector }\end{array}$ & BUIL & $\begin{array}{l}\text { Unemployment rate in the } \\
\text { building sector }\end{array}$ & SEPE (www.sepe.es) & $\begin{array}{l}\text { Unemployed people in the building sector/ } \\
\text { labor force }\end{array}$ \\
\hline $\begin{array}{l}\text { Unemployment rate in the } \\
\text { services sector }\end{array}$ & SERV & $\begin{array}{l}\text { Unemployment rate in the } \\
\text { services sector }\end{array}$ & SEPE (www.sepe.es) & $\begin{array}{l}\text { Unemployed people in the services sector/ } \\
\text { labor force }\end{array}$ \\
\hline GDPpc & GDPpc & $\begin{array}{l}\text { Gross Domestic product } \\
\text { per capita }\end{array}$ & INE (www.ine.es) & GDP in thousands $€ /$ labor force \\
\hline
\end{tabular}




\subsection{Statistic Methodology}

In order to empirically test whether the behavior of the demographic and socioeconomic variables can influence the evolution of the financial capacity of local governments to contribute to sustainable development, we use the methodology panel data, which has been the technique most used for the latest research in public finance $[2,19,72,74]$, since it reduces multicollinearity and improves efficiency of the model [75]. Therefore, our sample is composed by a vector of variables of $\mathrm{N}$ individuals (139 municipalities) for T periods (2006-2014). Therefore, we used the following equation:

$$
\begin{aligned}
& \mathrm{FS}_{\text {it }}=\beta_{0}+\beta_{1} \mathrm{GPOP}_{\text {it }}+\beta_{2} \mathrm{DP} 16_{\text {it }}+\beta_{3} \mathrm{DP}_{6} 5_{\text {it }}+\beta_{4} \mathrm{INM}_{\text {it }}+\beta_{5} \mathrm{EDU}_{-} \mathrm{s}_{\mathrm{it}}+\beta_{6} \mathrm{EDU}_{-} \mathrm{m}_{\mathrm{it}} \\
& +\beta_{7} \mathrm{CC}_{\text {it }}+\beta_{8} \mathrm{AGR}_{\mathrm{it}}+\beta_{9} \mathrm{IND}_{\mathrm{it}}+\beta_{10} \mathrm{BUIL}_{\mathrm{it}}+\beta_{11} \mathrm{SER}_{\mathrm{it}}+\beta_{12} \mathrm{GDPpc}_{\mathrm{it}}+\mathrm{u}_{\mathrm{it}}
\end{aligned}
$$

where " $\mathrm{i}$ " is the $\mathrm{i}$-th unit cross (Spanish municipalities) and " $\mathrm{t}$ " is the time (year).

In this technique, the error $\left(u_{i t}\right)$ is composed by $e_{i t}$ (the error term) and $\alpha_{i}$ (unobservable heterogeneity) designed to measure the unobservable characteristics of the local governments that have a significant impact on financial sustainability.

In order to determine the specific model to be followed, we consider the possible existence of endogeneity, which is an important concern in testing the effects of some independent variables, such as financial ones, on financial sustainability. Models that do not consider this possibility could fail to represent financially sustainable policy within local governments [76].

Therefore, we estimate our model with the robust system-generalized method of moments (SGMM) [77,78], which is the most powerful tool to control for the possible endogeneity between the variables and the error term $[75,76,79]$. This technique uses the lagged levels of the endogenous regressors as instrumental variables and combines the moment conditions for the equations in first-differences with additional moment conditions implied for equations in level to improve efficiency [80]. Furthermore, in order to take into account the heteroscedasticity problems, we applied the two-step estimation.

Furthermore, we perform the Arellano-Bond test (test $\mathrm{m}$ ) to check the existence of serial correlation, and the Hansen test to verify that the instruments used to control the endogeneity are adequate [81]. In our analysis, the Arellano-Bond test $(p=0.442)$ and Hansen test $(p=0.289)$ confirm the consistency of our model (Table 4). Therefore, we have obtained robust results that allow us to properly support the findings related to the purpose of the paper, controlling for any type of endogeneity and multicollinearity that may exist between the variables.

Table 4. Hypothesis Testing.

\begin{tabular}{cccc}
\hline Test & & & \\
\hline \multirow{2}{*}{ Arrellano-Bond test } & $\operatorname{Ar}(1)$ & $\mathrm{z}=-3.27$ & $\operatorname{Pr}>\mathrm{z}=0.001$ \\
& $\operatorname{Ar}(2)$ & $\mathrm{z}=0.77$ & $\mathrm{Pr}>\mathrm{z}=0.442$ \\
\hline Hansen test & ${\operatorname{Test~} \mathrm{chi}^{2}(80)}^{2}$ & 86.56 & $\mathrm{Pr}>\mathrm{chi}^{2}=0.289$ \\
\hline Sample & $N=1242$ & $n=139$ & $\mathrm{~T}=9$ \\
\hline Instruments & 102 & & \\
\hline
\end{tabular}

Source: Stata and own elaboration; Note: collapse option was used in order to reduce the instruments [82].

\section{Empirical Results}

Table 5 shows that the most heterogeneous variable is the financial sustainability followed by the GDPpc. Moreover, the descriptive statistic indicates that the economic crisis has caused the behavior of the financial sustainability was more homogeneous between municipalities (between) than within the same municipality over time (within), suggesting a strong effect of the uncontrollable factors of local governments on their ability to contribute to sustainable development. This same 
behavior, it can be observed in the unemployment rate in the building and services sector and in the population growth, although with less intensity. However, the behavior of the rest of variables is different, since their evolution is more uniform within each municipality over time (within) than between municipalities (between).

Table 5. Descriptive statistic.

\begin{tabular}{|c|c|c|c|c|c|}
\hline Variable & Category & Mean & Stander Des. & Min. & Max. \\
\hline \multirow{3}{*}{ FS } & overall & \multirow{3}{*}{112.3424} & 217.1185 & -1040.9525 & 2517.8884 \\
\hline & between & & 113.8477 & -258.4299 & 625.4617 \\
\hline & within & & 187.5232 & -869.6793 & 2004.7692 \\
\hline \multirow{3}{*}{ GPOP } & overall & \multirow{3}{*}{0.8929} & 1.9433 & -13.1100 & 11.1600 \\
\hline & between & & 1.1481 & -1.0133 & 5.6878 \\
\hline & within & & 1.5706 & -13.2971 & 8.9596 \\
\hline \multirow{3}{*}{ DP16 } & overall & \multirow{3}{*}{23.8924} & 3.3564 & 15.4426 & 33.6056 \\
\hline & between & & 3.2366 & 16.8928 & 33.1235 \\
\hline & within & & 0.9262 & 19.5583 & 27.7212 \\
\hline \multirow{3}{*}{ DP65 } & overall & \multirow{3}{*}{21.8223} & 6.5546 & 5.2089 & 43.1236 \\
\hline & between & & 6.3509 & 6.0774 & 36.7379 \\
\hline & within & & 1.6998 & 15.5009 & 29.0517 \\
\hline \multirow{3}{*}{ INM } & overall & \multirow{3}{*}{12.8916} & 9.5200 & 0.9416 & 53.5426 \\
\hline & between & & 9.4573 & 1.2198 & 51.6375 \\
\hline & within & & 1.3294 & 4.9366 & 16.6981 \\
\hline \multirow{3}{*}{ EDU_S } & overall & \multirow{3}{*}{16.4939} & 4.9083 & 7.8842 & 28.9134 \\
\hline & between & & 4.7873 & 10.1453 & 26.9107 \\
\hline & within & & 1.1494 & 13.2710 & 19.2946 \\
\hline \multirow{3}{*}{ EDU_m } & overall & \multirow{3}{*}{27.0080} & 3.3426 & 14.8614 & 35.6537 \\
\hline & between & & 3.1479 & 17.9469 & 32.2113 \\
\hline & within & & 1.1522 & 22.4142 & 30.6586 \\
\hline \multirow{3}{*}{ COMP } & overall & \multirow{3}{*}{26.5570} & 9.9558 & 5.3237 & 72.7403 \\
\hline & between & & 9.0958 & 7.1929 & 60.5994 \\
\hline & within & & 4.1123 & 13.5947 & 40.1703 \\
\hline \multirow{3}{*}{ AGRI } & overall & \multirow{3}{*}{0.2801} & 0.3681 & 0.0087 & 3.2464 \\
\hline & between & & 0.3263 & 0.0225 & 1.8879 \\
\hline & within & & 0.1723 & -0.6933 & 1.8963 \\
\hline \multirow{3}{*}{ IND } & overall & \multirow{3}{*}{1.3662} & 1.0860 & 0.1150 & 9.7473 \\
\hline & between & & 1.0179 & 0.2135 & 8.2985 \\
\hline & within & & 0.3870 & -0.8007 & 3.6968 \\
\hline \multirow{3}{*}{ BUIL } & overall & \multirow[t]{3}{*}{1.9134} & 1.1454 & 0.1163 & 6.8437 \\
\hline & between & & 0.7562 & 0.3716 & 4.6983 \\
\hline & within & & 0.8624 & -1.1028 & 4.0588 \\
\hline \multirow{3}{*}{ SERV } & overall & \multirow{3}{*}{7.7295} & 3.0206 & 1.9816 & 17.2598 \\
\hline & between & & 1.7078 & 4.2028 & 12.5013 \\
\hline & within & & 2.4953 & 1.6251 & 13.3423 \\
\hline \multirow{3}{*}{ GDPpc } & overall & \multirow{3}{*}{56.8810} & 94.6511 & 2.0075 & 778.5317 \\
\hline & between & & 94.8475 & 2.1972 & 764.1077 \\
\hline & within & & 4.5574 & 5.1160 & 97.2092 \\
\hline
\end{tabular}

Source: Stata 12 and own elaboration.

Regarding demographic variables, the population grows an average of $0.89 \%$ per year (Table 5). In addition, the Table 5 shows that there is more dependent population under $16(23.89 \%)$ than those over $65(21.82 \%)$, but together they represent nearly the $50 \%$ of the labor force. Moreover, the behavior of the dependent population under 16 is more homogeneous than those over 65 . 
Finally, the mean of the immigrant population is $12.89 \%$, i.e., the $12.89 \%$ of the population are foreigners. However, it is a heterogeneous variable since the standard deviation is 9.52 and it could be different between municipalities (9.45). Thus, in our sample, there is a municipality which has only a $1.22 \%$ of foreigners (minimum) while there is a municipality which has $51.63 \%$ of foreigners (maximum).

Following the socioeconomic variables, specifically the human capital, Table 5 displays that the $16.49 \%$ of the labor force has a higher education (at least one degree) meanwhile the $27 \%$ of the labor force has an intermediate education (Secondary Bachelor, FP I or FP II). Therefore, most of the labor force is between illiterates and people with primaries studies.

Regarding the company's concentration, the statistic descriptive shows that, although the mean of this indicator is 26.55 ( 26.55 companies each mill inhabitants), the differences between municipalities are wide, since the municipality which has the minimum indicator has only 7.19 companies meanwhile the municipality with the higher indicators has 60.60 companies.

Analyzing the unemployment rate, the highest unemployment rate is in the service sector (7.73), followed by the unemployment rate in the building sector (1.91), industry (1.36) and, finally, unemployment in agriculture (0.28). The unemployment rate in the building and services sectors are the only independent variables that have greater homogeneity between municipalities than within the same municipality over time. This similar behavior between regions could have been provoked by financial problems of the burst of the housing bubble.

Finally, the GDP is the most heterogeneous independent variable, which has a stronger difference between municipalities than within each municipality over time, showing the inequalities and imbalances in the economic development of the different territories.

Considering the statistic model, our empirical results (Table 6) display two types of influences on the financial sustainability of local governments. Firstly, we have identified three variables whose increase can influence positively on the financial sustainability: the financial sustainability of the previous year (0.000), the labor force with intermediate education (0.002) and the companies concentration (0.000).

Table 6. The Model.

\begin{tabular}{cccc}
\hline Variable & Acronym & Coefficient & Std. Error \\
\hline Financial Sustainability previous year & FS & $0.3219^{* * *}$ & 0.0207809 \\
Population Growth & GPOP & -4.674077 & 4.313791 \\
Dependent Population under 16 & DP16 & $-12.68625^{* * *}$ & 4.080064 \\
Dependent Population over 65 & DP65 & $-4.353538^{*}$ & 2.243429 \\
Immigrant Population & INM & $-1.532509^{* *}$ & 0.6675593 \\
Labor force with higher education & EDU_s & $-4.90164^{* * *}$ & 1.392481 \\
Labor force with intermediate education & EDU_m & $9.730358^{* * *}$ & 3.133862 \\
Companies concentration & CC & $2.324703^{* * *}$ & 0.4986177 \\
Unemployment rate in Agricultural sector & AGRI & $-34.42532^{* *}$ & 17.3073 \\
Unemployment rate in the Industrial sector & IND & -0.7780327 & 5.666835 \\
Unemployment rate in the building sector & BUIL & $-20.16096^{* *}$ & 8.218348 \\
Unemployment rate in the services sector & SERV & $-8.16308^{* *}$ & 3.44417 \\
GDPpc & GDPpc & -0.0364974 & 0.0391285 \\
Constant & Cons & 312.0584 & 201.9892 \\
\hline
\end{tabular}

Source: Own elaboration based on the test performed in Stata 12; Note: Wald $\mathrm{chi}^{2}(21)=3518.34^{* * *}$; *** Significant at $1 \% ;{ }^{* *}$ Significant at $5 \% ;{ }^{*}$ Significant at $10 \%$ level; Fixed effect of time considered; All variables are treated as endogenous, except for the year dummies.

On the other hand, our results show some factors whose increase could reduce the financial sustainability of local governments. These factors are the dependent population under $16(0.002)$, the dependent population over 65 (0.052), the immigrant population (0.022), the labor force with higher 
education (0.005), the unemployment rate in the agricultural sector (0.047), in the building sector $(0.014)$ and in the service sector (0.018).

However, we have been unable to find an evident influence of the population growth (0.219), the unemployment rate in the industrial sector $(0.891)$ and the GDPpc $(0.351)$ on the financial sustainability of local governments.

Taking into account the socioeconomic variables, our study suggests that the intermediate education has a positive effect $(\beta=9.73$ ) on the financial sustainability, meanwhile, the higher education has a negative effect $(\beta=-4.90)$. In addition, our results show that the companies concentration has a positive and statistically significant relationship with financial sustainability ( $\beta=2.32$ ).

In addition, we have confirmed that the unemployment rate has a negative influence on the finances of local governments, which is significant in the case of the agricultural sector, the building sector and services sector. Finally, we have found no significant influence of GDPpc on the financial sustainability of local governments.

\section{Discussion}

This study has carried on an empirical research with 139 Spanish Local Governments in order to identify factors that may influence the financial sustainability of these organizations. This study contributes to previous research with important and appropriate findings, for which we answer the following research questions:

$R Q 1$-Does the human capital formation influence on the financial sustainability of Local Governments?

We have found a positive and statistically significant relationship between intermediate education and financial sustainability, although the higher education has a negative effect. In this sense, the intermediate education could influence on the financial sustainability through its positive influence on productivity [41,42], on the wealth of the economy [37-42], and hence, on the regional sustainable development and economic growth $[39,40,83,84]$. This positive effect could respond to the entry age in the labor market, which is lower for intermediate graduates than for higher graduates since the duration of their studies is shorter. This fact could provoke a higher volume of intermediate graduates which are working and generating revenues which could contribute to the financial sustainability of the municipalities where they are working.

A possible explanation of this negative effect of the population with higher education could be due to both the great unemployment rate of this population during the years under study and to the high number of graduates who are hired with a similar remuneration to the intermediate educational levels.

\section{$R Q 2$-Does the company's concentration affect the financial sustainability of Local Governments?}

Our findings achieved shown a positive and statistically significant relation with the companies concentration and it confirms prior research. Therefore, we can confirm that the companies concentration influence positively on the financial sustainability, through the taxes collected [44].

This favorable repercussion on financial sustainability could be due to the invoiced revenues by companies implies an increase of national taxes such as the VAT and PIT, and based on the Spanish funding model, local governments have the right to receive a partition of these national taxes. However, Spanish local governments do not bear the possible expenditures derived from the installation of companies, such as subventions and unemployment allowance, which are borne by regional or national budget.

\section{$R Q 3$-Does the unemployment rate influence on financial sustainability of Local Governments?}

In this case, the unemployment rate has a negative influence on the financial of local governments, as the findings of previous literature and international organizations had shown [3,47,48]. However, our findings represent an advance because they support that the unemployment rate could affect specifically on the financial capacity of local governments to contribute to sustainable development. 
In addition, we have found that unemployment rates, which most affect the municipal sustainability, are those related to the agricultural sector, followed by the unemployment rate in the building and services sector. However, we have found no evidence of the influence of the unemployment rate in the industrial sector.

These findings are consistent with the structure of economic sector in Spain. Firstly, the agricultural sector is supported by strong contributions from EU grants and subsidies and Spanish Governments (State, Regional or Local). On the other hand, nowadays, the building and services sector is taken into a severe economic crisis, when this sector was the main motor of the Spanish economy in 2004 and 2005 [85]. Finally, the weight of industrial sector in the Spanish economy has been falling over time [85], and although it is showing improvement, it still has not influenced on economic growth.

Moreover, the unemployment allowances are not borne by local government but by regional and national governments. Therefore, the negative effect of the unemployment rate on local government financial sustainability could be due to the unemployed people pay fewer taxes and buy fewer houses and vehicles, and this fact causes a decrease in the participation in national taxes and in local taxes.

$R Q 4$-Does the economic level of a region impact on the financial sustainability of Local Governments?

Regarding the economic level of a region we have found no significant influence of GDP on the financial sustainability, although previous studies showed a positive relationship with the public revenues and could help local governments to reduce the debt [50-53]. This result could be due to an increase in GDP does not always imply an increase in the national taxes that local governments participate. The increase in companies' invoicing does not always involve greater recruitment of personnel, but greater inversion in technologies which provokes that there is not an increase in revenues derived by PIT.

\section{RQ 5 -Does the population structure affect financial sustainability of Local Governments?}

Regarding the demographic factors, due to the insignificance effect of the population growth on the financial sustainability, our findings cannot confirm the findings of prior research. Therefore, although previous studies have pointed out that the population growth could increase the demand for services [54-56], and thus, it could provoke an increase in public borrowing and spending [57] and debt [6], we could affirm that this variable do not affect the financial sustainability and, therefore, the capacity of the local governments to the contribution to the sustainable development. Therefore, the effect of the increase in population on financial sustainability could depend on its influence on national taxes (that local governments participate) and on the local taxes, which depend on the shopping behavior of citizens, such as property tax or tax on motor vehicles.

However, our findings regarding the dependent population are in the same line than previous studies and international organizations. Firstly, we can confirm the worry of the international organizations regarding this population $[16,60]$ because it has become a risk factor for the financial sustainability. Secondly, according to prior research this type of population could influence negatively on the financial sustainability through the negative influence on public expenditures and revenues [57,61], which are two dimensions of the financial sustainability [25,62].

In this regards, the influence of dependent population under 16 is higher than population over 65 , because the Spanish education system is public, and the education is compulsory up to age 16, where the primary and high schools are financed with public funds, and the students received grants and subsidies. Hence, it has a negative influence on public financial expenditures and revenues, and finally, on financial sustainability.

Likewise, our finding about the immigrant population suggests that the negative effect of the increase of the public services demanded which could raise the accumulated debt $[6,65]$ and public expenditures $[57,66]$ are higher than the positive effect that this population could imply regarding the population balance $[60,64]$ or the public revenues. 
Ultimately, our results show that the negative influence of the dependent population and immigrant population could be due to the expenditures associated with this type of population (subsidies, subventions, aids, childcare services ... ) are higher than their contribution to national and local taxes.

\section{Conclusions}

Prior research and international organizations (IMF, EU, OECD, UN) have concluded that the crisis of government finances caused serious imbalances between the objectives of the economic growth, which has led the financial sustainability of public services to become an issue of particular concern to researchers, policy makers, public managers, citizens and other stakeholders. In this context, the link between the efficiency of public management and regional economic development has led to both, prior research and international organizations, to recognize that governments are called to play a key role in promoting sustainable development, through environmental, economic and social policies based on the financial sustainability of public services.

Based on an empirical research of 139 local governments of a large population during the period 2006-2014, we have identified some factors that can influence on the financial sustainability in these governments.

Firstly, our findings show variables whose increase could favor the financial sustainability, specifically the population with intermediate educational level, the companies' concentration and the financial sustainability of the previous year. In parallel, we have obtained empirical evidence that supports the harmful effect of the increase of other variables on the financial sustainability, namely: population aged under 16, unemployment rate in agricultural, building and service sector, immigrant population, population with higher education and, to a lesser extent, population over 65 years.

These findings are unpublished and contribute to prior research regarding specific influencing factors on the financial sustainability of local governments. Indeed, several previous studies concluded the negative impact of some variables (dependent population, immigration, unemployment rate) on the budget deficit, debt or tax burden, but none of them analyzed their impact on the financial sustainability of public services. However, our findings have identified factors whose evolution over time (increase or decrease) could affect, in particular, to the financial sustainability of local governments.

In concordance with this, the possible explanations for our findings could be due to the entry age of young people to the labor market, as well as, the influence of population factors, unemployment, and dependent and immigrant population on the evolution of local public revenues derived from their participation in national and regional taxes and on the local direct taxes.

These findings are relevant to policymakers and public managers interested in promoting the financial sustainability in local governments. Firstly, our findings indicate that the behavior of some variables (mainly population under 16 , immigrant population, companies concentration and unemployment rate by sector) could display alerting signals to take financial decisions that prevent any risk to the sustainability of public services.

Secondly, the influencing factors which we have identified can guide governmental policies aimed at promoting the financial sustainability, such as the promotion of employment in certain sectors, the incentives for business creation and the contribution to the educational level of the population.

In summary, our findings identify socioeconomic factors that affect the financial sustainability, revealing that the educational level of the population, the evolution of unemployment by sector of activity, the immigrant population and the dependent population, are determining factors to be taken into account to assess, manage and enhance the financial sustainability of public services.

Finally, these findings have revealed the opportunity and interest for future research such as: (a) comparative analysis of the effect of political factors on different administrative cultures; (b) study of the influence of political factors on local government with smaller size, to determine the size effect; (c) comparative analysis of the impact of political factors and socioeconomic factors in municipalities of different sizes. 
Acknowledgments: This research was carried out with financial support from the Regional Government of Andalusia (Spain), Department of Innovation, Science and Enterprise (Research project number P11-SEJ-7700) and the Spanish Ministry of Education, Culture and Sports under Grant (FPU13/05949).

Author Contributions: Manuel Pedro Rodríguez Bolívar and Andrés Navarro Galera have analyzed and written the theoretical framework of the research. Laura Alcaide Muñoz and María Deseada López Subirés have undertaken and written the empirical section of the paper. All of them have analyzed the data and written the conclusion section of the paper.

Conflicts of Interest: The authors declare no conflict of interest.

\section{References}

1. Méndez, R.; Abad, L.D.; Echaves, C. Atlas de la Crisis. Impactos Socioeconómicos y Territorios Vulnerables en España; Colección Crónica; Tiranch Lo Blanch: Valencia, Spain, 2015.

2. Rodríguez Bolívar, M.P.; Navarro Galera, A.; Alcaide Muñoz, L.; López Subirés, M.D. Risk Factors and Drivers of Financial Sustainability in Local Government: An Empirical Study. Local Gov. Stud. 2016, 42, 29-51. [CrossRef]

3. EU. Fiscal Sustainability Report; EU: Brussels, Belgium, 2012.

4. Government of Spain. La Programación Regional y Sus Instrumentos; Informe Anual 2010; Government of Spain: Madrid, Spain, 2012.

5. Bank of Spain. Boletín Estadístico 12/2014; Bank of Spain: Madrid, Spain, 2014.

6. Guillamón, M.D.; Benito, B.; Bastida, F. Evaluación de la Deuda Pública Local en España. Revista Española de Financiación y Contabilidad 2011, 40, 251-285. [CrossRef]

7. Ruiz-Huerta Carbonell, J.; García Díaz, M.A. El Endeudamiento de las Comunidades Autónomas: Límites y Problemas en el Contexto de la Crisis Económica. Revista d'Estudis Autonòmics i Federals 2012, 15, 124-162.

8. Cabaleiro, R.; Buch, E.; Vaamonde, A. Developing a Method to Assessing the Municipal Financial Health. Am. Rev. Public Adm. 2013, 43, 729-751. [CrossRef]

9. Goverment of Spain. Organic Law 2/2012 of 27 April 2012 on Fiscal Stability and Financial Sustainability; Goverment of Spain: Madrid, Spain, 2012.

10. Afonso, A.; Jalles, J.T. Fiscal Sustainability: A Panel Assessment for Advanced Economies. Appl. Econ. Lett. 2015, 22, 925-929. [CrossRef]

11. Rodríguez, M.P.; Navarro, A.; Alcaide, L.; López, M.D. Factors Influencing Local Government Financial Sustainability: An Empirical Study. Lex Localis J. Local Self-Gov. 2014, 12, 31-54. [CrossRef]

12. EU. Stability and Growth Pact; EU: Strasbourg, France, 2012.

13. EC. Council Directive 2011/85/EU of 8th November 2011 on Requirements for Budgetary Frameworks of the Member States; EC: Brussels, Belgium, 2011.

14. IMF. De la Estabilización a un Crecimiento Sostenido: Informe Anual 2014 del Fondo Monetario Internacional; IMF: Washington, DC, USA, 2014.

15. NAO. Financial Sustainability of Local Authorities. Department for Communities and Local Government; TSO (The Stationery Office): London, UK, 2013.

16. IFAC. Reporting on the Long-Term Sustainability of a Public Sector Entity's Finances; IFAC: New York, NY, USA, 2012.

17. IFAC. Recomended Practice Guideline. Reporting on the Long-Term Sustainability of an Entity's Finances; IFAC: Toronto, ON, Canada, 2013.

18. IFAC. Handbook of International Public Sector Accounting Pronouncements; IFAC: New York, NY, USA, 2014.

19. Navarro-Galera, A.; Rayo-Cantón, S.; Lara-Rubio, J.; Buendía-Carrillo, D. Loan Price Modelling for Local Governments using Risk Premium Analysis. Appl. Econ. 2015, 47, 6257-6276. [CrossRef]

20. Batabyal, A.A. Sustainable Growth and Development in a Regional Economy. Reg. Stud. 2016, 50, 922-923. [CrossRef]

21. Carrion-I-Silvestre, J.L. Fiscal Deficit Sustainability of the Spanish Regions. Reg. Stud. 2015, 3404, 1-12. [CrossRef]

22. De la Fuente, Á. Las Finanzas Autonómicas en 2014 y Entre 2003 y 2014. FEDEA and CSIC, 2015. Available online: http:/ / documentos.fedea.net/pubs/eee/eee2015-10.pdf (accessed on 22 January 2016).

23. Alcaide, L.; Rodríguez, M.P. Determining Factors of Transparency and Accountability in Local Governments: A Meta-Analytic Study. Lex Localis 2015, 13, 129. 
24. Kloha, P. Someone to Watch over Me: State Monitoring of Local Fiscal Conditions. Am. Rev. Public Adm. 2005, 35, 236-255. [CrossRef]

25. Zafra-Gómez, J.L.; López-Hernández, A.M.; Hernández-Bastida, A. Developing an Alert System for Local Governments in Financial Crisis. Public Money Manag. 2009, 29, 175-181. [CrossRef]

26. Pirtea, M.G.; Nicolescu, A.C.; Mota, P.R. An Empirical Study on Public Debt's Determinants: Evidence from Romania. Transylv. Rev. Adm. Sci. 2013, 9, 144-157.

27. Levine, H.; Justice, J.B.; Scorsone, E.A. Handbook of Local Government Fiscal Health; Jones \& Bartlett Learning: Burlington, MA, USA, 2013.

28. Rivenbark, W.C.; Roenigk, D.J.; Allisonr, G.S. Conceptualizing Financial Condition in Local Government. J. Public Budg. Account. Financ. Manag. 2010, 22, 149-177.

29. Chaney, B.A.; Mead, D.M.; Schermann, K.R. The New Governmental Financial Reporting Model: What if Means for Analyzing Government Financial Condition. J. Gov. Financ. Manag. 2002, 51, 26-31.

30. Hendrick, R. Assessing and Measuring the Fiscal Heath of Local Governments: Focus on Chicago Suburban Municipalities. Urban Aff. Rev. 2004, 40, 78-114. [CrossRef]

31. Wang, X.H.; Dennis, L.; Tu, Y.S. Measuring Financial Condition: A Study of U.S. States. Public Budg. Financ. 2007, 27, 1-21. [CrossRef]

32. Williams, B.; Wilmshurst, T.; Clift, R. The role of accountants in sustainability reporting-A local government study. In Proceedings of the Sixth Asia Pacific Interdisciplinary Research in Accounting Conference, Sydney, Australia, 12-13 July 2010; pp. 1-18.

33. Law 7/1985, 2 April, Regulation of the Basis of Local Regimes 2011. pp. 1-96. Available online: http:/ /www. boe.es/buscar/act.php?id=BOE-A-1985-5392\&tn=1\&p=20131230\&vd=\#a25 (accessed on 9 September 2016). (In Spainish).

34. Goverment of Spain. Royal Legislative Decree 2/2004 of 5 March, Approving the Revised Text of the Law Regulating Local Tax Authorities; Goverment of Spain: Madrid, Spain, 2004.

35. Rodríguez, M.P.; Navarro, A.; Alcaide, L. New Development: The Role of Accounting in Assessing Local Government Sustainability. Public Money Manag. 2014, 34, 233-236.

36. Barro, R.J. Economic Growth in a Cross Section of Countries. Q. J. Econ. 1991, 106, 407-443. [CrossRef]

37. Florida, R.; Mellander, C.; Stolarick, K. Inside the Black Box of Regional Development-Human Capital, the Creative Class and Tolerance. J. Econ. Geogr. 2008, 8, 615-649. [CrossRef]

38. Hansen, H.K.; Winther, L. Regional Development and the Impact of the Public Sector in Denmark: Employment Growth and Human Capital. Geogr. Tidsskr. Dan. J. Geogr. 2014, 114, 156-168. [CrossRef]

39. Agiomirgianakis, G.; Asteriou, D.; Monastiriotis, V. Human Capital and Economic Growth Revisited: A Dynamic Panel Data Study. Int. Adv. Econ. Res. 2002, 8, 177-187. [CrossRef]

40. Taşel, F.; Bayarçelik, E.B. The Effect of Schooling Enrolment Rates on Economic Sustainability. Procedia Soc. Behav. Sci. 2013, 99, 104-111. [CrossRef]

41. Breton, T.R. The Role of Education in Economic Growth: Theory, History and Current Returns. Educ. Res. 2013, 55, 121-138. [CrossRef]

42. Psacharopoulos, G.; Patrinos, H.A. Returns to Investment in Education: A Further Update. Educ. Econ. 2004, 12, 111-134. [CrossRef]

43. Baptista, R.; Escária, V.; Madruga, P. Entrepreneurship, Regional Development and Job Creation: The Case of Portugal. Small Bus. Econ. 2007, 30, 49-58. [CrossRef]

44. Sutaria, V.; Hicks, D.A. New Firm Formation: Dynamics and Determinants. Ann. Reg. Sci. 2004, 38, $241-262$. [CrossRef]

45. Fritsch, M.; Mueller, P. The Effect of New Business Formation on Regional Development over Time: The Case of Germany. Small Bus. Econ. 2007, 30, 15-29. [CrossRef]

46. Aceleanu, M.; Serban, A.; Burghelea, C. "Greening" the Youth Employment-A Chance for Sustainable Development. Sustainability 2015, 7, 2623-2643. [CrossRef]

47. Benito, B.; Bastida, F.; Muñoz, M.J. Explanatory Factors of the Muncipal Fiscal Burden. Rev. Contab. 2010, 13, 239-283.

48. Zafra-Gomez, J.L.; Lopez-Hernandez, A.M.; Hernandez-Bastida, A. Evaluating Financial Performance in local Government: Maximizing the Benchmarking Value. Int. Rev. Adm. Sci. 2009, 75, 151-167. [CrossRef]

49. Capalbo, E.; Grossi, G. Assessing the influence of socioeconomic drivers on Italian municipal financial destabilization. Public Money Manag. 2014, 34, 107-114. [CrossRef] 
50. Gupta, A.S. Determinants of Tax Revenue Efforts in Developing Countries. Available online: https://www. imf.org/external/pubs/ft/wp/2007/wp07184.pdf (accesed on 26 February 2016).

51. Feld, L.P.; Kirchgässner, G. Public debt and budgetary procedures: Top down or bottom up? Some evidence from Swiss municipalities. In Fiscal Institutions and Fiscal Performance; Poterba, J.M., von Hagen, J., Eds.; University of Chicago Press: Chicago, IL, USA, 1999; pp. 151-180.

52. Ghosh, A.R.; Kim, J.I.; Mendoza, E.G.; Ostry, J.D.; Qureshi, M.S. Fiscal Fatigue, Fiscal Space and Debt Sustainability in Advanced Economies. Econ. J. 2013, 123, F4-F30. [CrossRef]

53. Potrafke, N.; Reischmann, M. Fiscal Transfers and Fiscal Sustainability; Public Finances: Munich, Germany, 2014.

54. Balatsky, A.; Balatsky, G.; Borysov, S. Resource Demand Growth and Sustainability Due to Increased World Consumption. Sustainability 2015, 7, 3430-3440. [CrossRef]

55. Conard, B. Some Challenges to Sustainability. Sustainability 2013, 5, 3368-3381. [CrossRef]

56. Wang, X.; Liou, K.T. Assessing the Change in Financial Condition: An Analysis of Panel Data from U.S. States. J. Public Budg. Account. Financ. Manag. 2009, 21, 165-197.

57. Choi, S.O.; Bae, S.-S.; Kwon, S.-W.; Feiock, R. County Limits: Policy Types and Expenditure Priorities. Am. Rev. Public Adm. 2010, 40, 29-45. [CrossRef]

58. Lago Peñas, S.; Fernández Leiceaga, X. La Finanzas Autonómicas: Expansión y Crisis, $2002-2012$. Papeles Econ. Española 2013, 138, 129-146.

59. Lutz, W.; Sanderson, W.C.; O'Neill, B.C. Conceptualizing Population In Sustainable Development: From "Population Stabilization" to "Population Balance.". In The End of World Population Growth in the 21st Century: New Challenges for Human Capital Formation and Sustainable Development; Earthscan: London, UK, 2004.

60. Eurostat. Sustainable Development in the European Union; Eurostat Statistics Explained: Luxembourg, 2015.

61. Gonçalves Veiga, L.; Veiga, F.J. Political Business Cycles at the Municipal Level. Public Choice 2007, 131, 45-64. [CrossRef]

62. Carr, J.B.; Karuppusamy, S. Reassessing the Link Between City Structure and Fiscal Policy: Is the Problem Poor Measures of Governmental Structure? Am. Rev. Public Adm. 2009, 40, 209-228. [CrossRef]

63. EC. Sustainability Report 2009; European Economy Series; EC: Luxembourg, 2009.

64. Eurostat. Migration and Migrant Population Statistics. Available online: http://ec.europa.eu/eurostat/ statistics-explained/index.php/Migration_and_migrant_population_statistics (accessed on 14 March 2016).

65. Schultz, C.; Sjostrom, T. Public Debt, Migration, and Shortsighted Politicians. J. Public Econ. Theory 2004, 6, 655-674. [CrossRef]

66. Chapman, J.I. State and Local Fiscal Sustainability: The Challenges. Public Adm. Rev. 2008, 68, S115-S131. [CrossRef]

67. Ministry of Finance and Public Administration. Report on the Compliance of the Objective of Budget Stability, and Public Debt and the Rule of Expenditures of FY2014; Ministry of Finance and Public Administration: Madrid, Spain, 2014.

68. Gallego, R.; Barzelay, M. Public Management Policymaking in Spain: The Politics of Legislative Reform of Administrative Structures, 1991-1997. Governance 2010, 23, 277-296. [CrossRef]

69. Fundación La Caixa. Informe Annual: Memoria Sostenibilidad 2013; Fundación La Caixa: Barcelona, Spain, 2013.

70. Benito, B.; Brusca, I.; Montesinos, V. The harmonization of government financial information systems: The role of the IPSASs. Int. Rev. Adm. Sci. 2007, 73, 293-317. [CrossRef]

71. CICA. Indicators of financial condition. In Public Sector Statements of Recommended Practice (SORP); CICA: Toronto, ON, Canada, 2009.

72. Benito, B.; Vicente, C.; Bastida, F. The Impact of the Housing Bubble on the Growth of Municipal Debt: Evidence from Spain. Local Gov. Stud. 2015, 41, 1-20. [CrossRef]

73. Burritt, R.L.; Schaltegger, S. Sustainability Accounting and Reporting: Fad or Trend? Account. Audit. Account. J. 2010, 23, 829-846. [CrossRef]

74. Zhu, L. Panel Data Analysis in Public Administration: Substantive and Statistical Considerations. J. Public Adm. Res. Theory 2013, 23, 395-428. [CrossRef]

75. Wooldridge, J.M. Introductory Econometrics: A Modern Approach, 4th ed.; Cengage Learning: $\mathrm{Mason}, \mathrm{OH}$, USA, 2009.

76. Prillaman, S.A.; Meier, K.J. Taxes, Incentives, and Economic Growth: Assessing the Impact of Pro-business Taxes on U.S. State Economies. J. Polit. 2014, 76, 364-379. [CrossRef] 
77. Arellano, M.; Bover, O. Another Look at the Instrumental Variable Estimation of Error-Components Models. J. Econom. 1995, 68, 29-51. [CrossRef]

78. Blundell, R.; Bond, S. Initial Conditions and Moment Restrictions in Dynamic Panel Data Models. J. Econom. 1998, 87, 115-143. [CrossRef]

79. Baltagi, B.H. Econometric Analysis of Panel Data, 4th ed.; John Wiley \& Sons, Ltd.: Chichester, UK, 2008.

80. Oto-Peralías, D.; Romero-Ávila, D.; Usabiaga, C. Does Fiscal Decentralization Mitigate the Adverse Effects of Corruption on Public Deficits? Eur. J. Polit. Econ. 2013, 32, 205-231. [CrossRef]

81. Arellano, M.; Bond, S. Some Tests of Specification for Panel Data: Monte Carlo Evidence and an Application to Employment Equations. Rev. Econ. Stud. 1991, 58, 277. [CrossRef]

82. Roodman, D. How to Xtabond2: An Introduction to Difference and System GMM in Stata. Stata J. 2009, 9, 86-136. [CrossRef]

83. OECD. The Well-being of Nations: The Role of Human and Social Capital; Organisation for Economic Co-Operation and Development: Paris, France, 2001.

84. Wilson, J.; Tyedmers, P.; Pelot, R. Contrasting and Comparing Sustainable Development Indicator Metrics. Ecol. Indic. 2007, 7, 299-314. [CrossRef]

85. INE (National Statistics Institute). Available online: http://www.ine.es (accessed on 29 July 2016).

(c) 2016 by the authors; licensee MDPI, Basel, Switzerland. This article is an open access article distributed under the terms and conditions of the Creative Commons Attribution (CC-BY) license (http://creativecommons.org/licenses/by/4.0/). 